\title{
Rutto sankarina ja konnana. Lukemistoa koronan aikaan
}

\author{
Pekka Vartiainen: Ruttovuosi-Kirjoituksia kaunokirjallisuuden epidemiakuvauksista. \\ Helsinki: Avain, 2021, 188 s.
}

Aiemmassa kirjallisessa tuotannossaan laaja-alaisesti länsimaisen kirjallisuushistorian periodeihin perehtynyt Helsingin yliopiston yleisen kirjallisuustieteen dosentti Pekka Vartiainen tarttuu tuoreimmassa teoksessaan Ruttovuosi - Kirjoituksia kaunokirjallisuuden epidemiakuvauksista mielenkiintoiseen aiheeseen eli tartuntatauteihin kirjallisuudessa. Aihe on myös samalla piinaavan ajankohtainen, sillä maailmamme on yhtäkkisesti muuttunut pandemiatarinoiden hallitsemaksi ja faktan ja fiktion väliset rajat tuntuvat hiuksen hienoilta. "Aivan kuin fiktiosta olisi tullut totta ja miten se, minkä kuvittelimme todeksi, olisi karkaamassa kauemmaksi tarinoiden, legendojen ja myyttien maailmaan", kuten Vartiainen johdantoluvussa "Koronavuosi" toteaa. Teos pysyttäytyykin jatkuvasti ankkuroituna tähän päivään, vaikka monet tapausesimerkit löytyvät kaukaisemmasta kirjallisuushistoriasta.

Ensimmäinen tunne teokseen tarttuessani oli objektiivinen, hyväksyvä nyökkäys kiinnostavan aiheen ja teosvalintojen suhteen. Teos pureutuu epidemiakuvauksiin aloittaen 1300-luvulta Giovanni Boccaccion Decameronesta ja kulkee "hyppien ja poukkoillen", kuten Vartiainen huomauttaa, läpi useiden ruton runtelemien miljöiden. Keskeiset teokset Daniel Defoen Ruttovuodesta Albert Camus'n Ruton kautta Mary Shelleyn The Last Maniin saavat ansaitsemansa huomion. Vartiainen omistaa oman lukunsa myös teoksille, joissa tauti jää taustalle, mutta kuitenkin teoksia perustelevaksi elementiksi, kuten Thomas Mannin teoksissa Kuolema Venetsiassa ja Taikavuori sekä Gabríel Garcia Márguezin teoksessa Rakkautta koleran aikaan ja Virginia Woolfin Mrs. Dallowayssa. Juuri tässä luvussa, jossa "taudit" piilevät taustalla, Vartiaisen analyysi on vahvimmillaan. Teoksissa esiintyviä tauteja luetaan konkretian ohella myös metaforina sekä teosten hahmojen identiteettejä ja psykologisia piirteitä peilaavina.

Ruttovuosi päättyy kahteen lyhyempään lukuun, joissa huomioidaan tuoreempia teoksia, kuten Jeff Longin Vuosi nolla, Philip Rothin Nemesis ja teoksen ainoa kotimainen esimerkki, Anni Kytömäen vuonna 2020 ilmestynyt Margarita. Alkuperäistä innostuksen tunnetta toki seurasi pienimuotoinen subjektiivinen harmitus ymmärtäessäni, että olin juuri viettänyt vuoden taustoittaen tietokirjaa kovin samanmoisista lähtökohdista eli epidemioista kirjallisuushistorioissamme, mutta Vartiainen ehti näiden koronavuosiemme saatossa jo valmistaa teoksensa aiheesta. Harmitus kuitenkin haihtui nopeasti teosta lukiessa. Seuraava objektiivisemmin ladattu looginen ajatus oli tietenkin pohtia, mitä teos sisältää ja mitä siitä jää puuttumaan. Mitaltaan sangen lyhyt teos ei tietenkään 
pysty kattamaan kaikkia epidemia- ja pandemiakirjallisuuden puolia, kuten se ei alaotsikkonsa "kirjoituksia kaunokirjallisuuden epidemiakuvauksista" mukaisesti pyrikään.

Kyseessä on kokoelma esseistisiä näkökulmia länsimaisen kirjallisuuden esityksiin epidemioista, joissa pääpaino on ymmärrettävästi useimmille kirjallisuudentutkijoille tutuissa, kirjallisuutemme kanonisoiduissa teksteissä. Toisaalta Vartiaisen populaari, suuremmalle yleisölle suunnattu helppolukuinen tietoteos kykenee olemaan yhtä aikaa monisyinen, älykäs ja mielenkiintoinen. Vartiainen kirjoittaa selkeästi ja pitää teoksensa luvut ytimekkäinä, mutta samalla tekee runsaasti mielenkiintoisia huomioita kohdeteoksistaan. Teoksen parhaimmistoa ovat etenkin alkupään luvut, joissa Vartiaisen tuntemus länsimaiden kirjallisuushistoriasta näkyy erityisesti. Vartiainen näkee traditionaaliset jatkumot ruton runtelemien maisemien halki Boccaccion Firenzestä vuodelta 1353, Defoen Lontooseen 1722, Manzonin Milanoon 1827 ja Camus'n Oraniin 1947. Hän toteaakin osuvasti alkusanoissaan, että "[r]utto lienee tämän kirjan sankari ja konna" (s.17). Rutto, monella eri nimellään, raivoaakin kirjallisen kulttuurimme taustalla halki vuosisatojen. Yhtäläisyydet kohdeteosten analyyseissä vuosien 2019-2021 "meidän maailmaamme" koronapandemiaan ovat ajoittain riipaisevia. Esimerkiksi Vartiaisen valitut lainaukset pandemian keskellä elävien ihmisten ilottomuuden ja toivottomuuden kokemuksista vaikkapa Margaret Atwoodin Herran tarhureista (2009) tai Edgar Allan Poen "Punaisen surman naamionäytelmässä" (1842) voisivat yhtä hyvin olla kirjoitettu keväällä 2020.

Teoksen loppupuolen tieteisfiktiota kohti kurkottava neljäs luku "Uhka ulkoavaruudesta" ja dystopioita tarkasteleva viides luku "Maailma vuonna nolla" jäävät itselleni spekulatiivisen fiktion ja dystopioiden tutkijana vajavaisemmiksi ja jättävät monia lajien näkökulmia huomioimatta. Teoksen lähdeluettelo osoittaa, että Vartiainen voisi kirjoittaa myös laajemmin esimerkiksi tieteisfiktion ja kauhukirjallisuuden epidemiakuvauksista. Esimerkiksi Dean R. Koontzin (alun perin nimellä Leigh Nicholls) julkaisema Pimeyden silmät (1981, uud. 1989) on ollut paljon esillä julkisuudessa pandemiavuosina, sillä teoksen vuoden 1989 jälkeen julkaistuissa painoksissa kirjassa riehuu Kiinassa kehitetty Wuhanilaiseksi nimitetty tappajavirus. Tämän kaltaiset puutteetkin ovat toki ymmärrettäviä, sillä tässä teoksen mitassa laajempiin ja kattavampiin esityksiin ei ole mahdollisuuksia. Samalla toki säilyy myös tilaus uusille, vieläkin laajemmille teoksille kiinnostavasta ja (valitettavasti) erittäin tätä päivää olevasta aiheesta.

Kaiken kaikkiaan teos on viihdyttävää luettavaa pandemian kourissa kesällä 2021 kyyhöttävälle kirjallisuudentutkijalle ja varmasti myös laajemmalle yleisölle. Teos on mielenkiintoinen esseistinen näkökulma epidemiakuvauksiin länsimaisen kirjallisuuden viimeisimpien 700 vuoden ajalta ja puolustaa paikkaansa aiheen tieteellisenä popularisointina.

Jyrki Korpua 